\title{
Erratum to: Background nitrous oxide emissions in agricultural and natural lands: a meta-analysis
}

\section{Dong-Gill Kim • Donna Giltrap • \\ Guillermo Hernandez-Ramirez}

Published online: 13 September 2013

(C) Springer Science+Business Media Dordrecht 2013

\section{Erratum to: Plant Soil \\ DOI 10.1007/s11104-013-1762-5}

The original version of this paper unfortunately contained errors.

In Abstract section, 'BNEN (median: 0.31 \& mean: $1.75 \mathrm{~kg} \mathrm{~N}_{2} \mathrm{O}-\mathrm{N} \mathrm{ha}^{-1} \mathrm{yr}^{-1}$ )' should be 'BNEN (median: 0.39 \& mean: $1.65 \mathrm{~kg} \mathrm{~N}_{2} \mathrm{O}-\mathrm{N} \mathrm{ha}^{-1} \mathrm{yr}^{-1}$ )'.

In Abstract section, 'from 600 and 307' should be 'from 600 and 383'.

In Methods and materials section 'A total of 600 and 307 data sets were found' should be 'A total of 600 and 383 data sets were found'.

In Result and discussion section, 'while median and mean of BNEN were 0.31 and $1.75 \mathrm{~kg}$
$\mathrm{N}_{2} \mathrm{O}-\mathrm{N}$ ha $^{-1} \mathrm{yr}^{-1}$, should be 'while median and mean of BNEN were 0.39 and $1.65 \mathrm{~kg} \mathrm{~N}_{2} \mathrm{O}-\mathrm{N}$ $\mathrm{ha}^{-1} \mathrm{yr}^{-1}$.

In Result and discussion section, "BNE in riparian area (median and mean: 2.0 and $7.7 \mathrm{~kg}$ $\mathrm{N}_{2} \mathrm{O}-\mathrm{N} \mathrm{ha}{ }^{-1} \mathrm{yr}^{-1}$, respectively) was significantly higher than in two other ecosystem types (i.e., boreal forest and tundra; Table 6)." should be "BNE in both riparian area and tropical forest were significantly higher than in boreal forest (Table 6)."

In Conclusion section "BNEN was higher in riparian zones than in boreal forests and tundra." should be "BNEN in both riparian zones and tropical forests were higher than in boreal forests."

The online version of the original article can be found at http:// dx.doi.org/10.1007/s11104-013-1762-5.

D.-G. Kim $(\bowtie)$

Wondo Genet College of Forestry and Natural Resources, Hawassa University,

Shashemene, Ethiopia

e-mail: donggillkim@gmail.com

D. Giltrap

Landcare Research,

Palmerston North 4442, New Zealand

G. Hernandez-Ramirez

Department of Renewable Resources, University of Alberta,

751 General Services Building,

Edmonton, AB T6G 2H1, Canada 
Table 6 should be as follows:

Table 6 Background nitrous oxide emissions in natural land (BNEN, unit: $\mathrm{kg} \mathrm{N}_{2} \mathrm{O}-\mathrm{N} \mathrm{ha}^{-1} \mathrm{yr}^{-1}$ ). This dataset includes positive $(n=366)$ and negative $(n=17)$ emissions

\begin{tabular}{llllllll}
\hline Type & Size & Min & Max & Median & Mean & Std. Dev. & Std. Error \\
\hline Tropical forest & 69 & -0.05 & 8.13 & $1.14^{\mathrm{a} \dagger}$ & 1.91 & 2.06 & 0.25 \\
Temperate forest & 149 & -0.50 & 7.30 & $0.30^{\mathrm{ab}}$ & 0.66 & 1.05 & 0.09 \\
Boreal forest & 9 & -0.02 & 0.78 & $0.12^{\mathrm{b}}$ & 0.18 & 0.24 & 0.08 \\
Tropical savannah & 21 & 0.02 & 1.65 & $0.51^{\mathrm{ab}}$ & 0.53 & 0.42 & 0.09 \\
Temperate grassland & 47 & 0.03 & 1.80 & $0.30^{\mathrm{ab}}$ & 0.46 & 0.41 & 0.06 \\
Desert & 3 & 0.11 & 0.40 & $0.22^{\mathrm{ab}}$ & 0.24 & 0.15 & 0.09 \\
Tundra & 5 & 0.01 & 1.17 & $0.07^{\mathrm{ab}}$ & 0.31 & 0.49 & 0.22 \\
Peatland & 50 & -0.11 & 95.20 & $0.14^{\mathrm{ab}}$ & 6.16 & 18.14 & 2.57 \\
Wetland & 24 & -0.09 & 3.24 & $0.39^{\mathrm{ab}}$ & 0.59 & 0.70 & 0.14 \\
Riparian & 6 & 0.35 & 24.35 & $2.98^{\mathrm{a}}$ & 7.05 & 9.32 & 3.80 \\
Total & 383 & -0.50 & 95.20 & 0.39 & 1.65 & 6.97 & 0.36 \\
\hline
\end{tabular}

${ }^{\dagger}$ Values in the same column followed by a different letter are significantly different $(P<0.05)$ according to all Pairwise Multiple Comparison Procedures (Dunn's Method)

Figure 4 should be as follows:

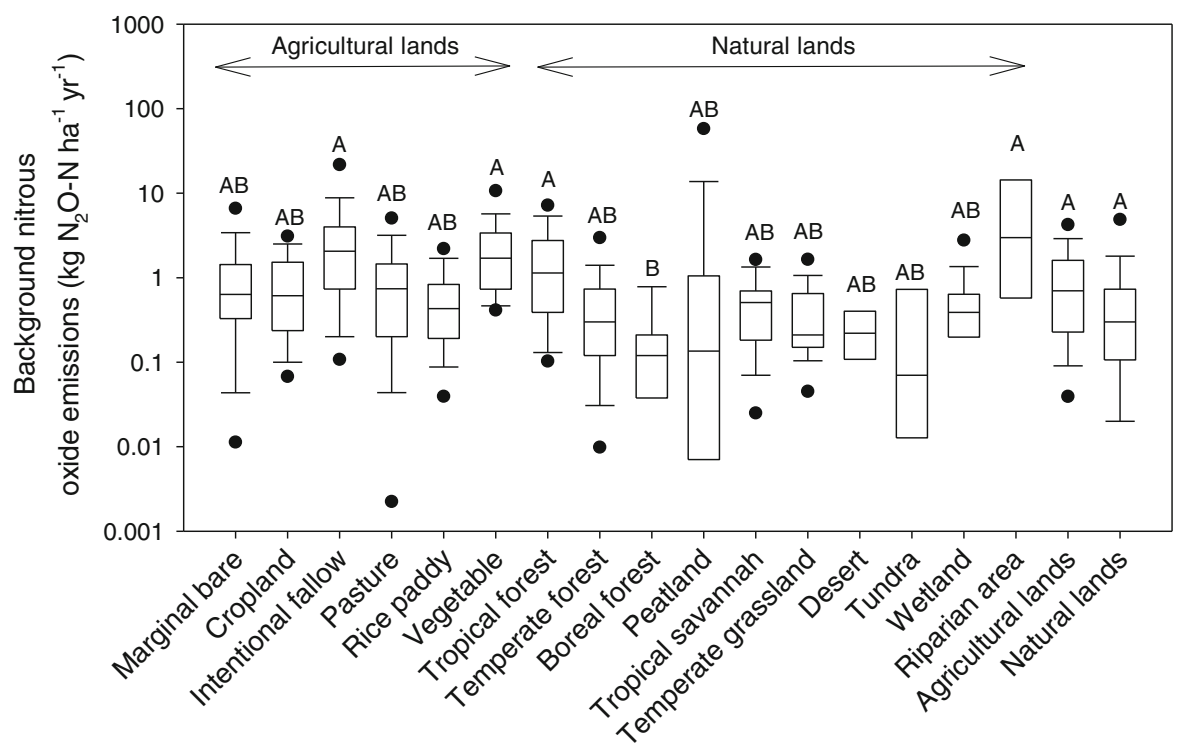

Fig. 4 Box plot representation of background nitrous oxide $\left(\mathrm{N}_{2} \mathrm{O}\right)$ emission (BNE) in agricultural and natural lands by land-use or ecosystem type. Lower and upper whiskers are 10th and 90th percentiles, lower and upper boundaries of the boxes are 25th and 75th percentiles and lines within a box are medians. Note that for improved visualization, $y$-axis is presented in logarithmic 10 scale. Land-use or ecosystem types labelled with the same letter are not significantly different according to Dunn test $(\alpha=0.05)$ 